\title{
Synthesis of 3-substituted 2-cyclohexenones through umpoled functionalization
}

\author{
Harim Lechuga-Eduardo, Eduardo Zarza-Acuña, Moisés Romero-Ortega* \\ Departamento de Química Orgánica, Facultad de Química, Universidad Autónoma del Estado de México, Paseo Colón/Paseo Tollocan, Toluca Estado de México, Mexico
}

\section{A R T I C L E I N F O}

\section{Article history:}

Received 11 May 2017

Revised 22 June 2017

Accepted 1 July 2017

Available online 4 July 2017

Keywords:

Umpolung

Metallation reaction

Electrophiles

Silyl enol ether

\begin{abstract}
A B S T R A C T
A new protocol to obtain 3-substituted 2-cyclohexenones, was developed by reversing the chemical reactivity of 2-cyclohexenone. One-pot synthesis of 3-substituted 2-cyclohexenones can be achieved by treatment of 3-phenylthiosilyl enol ether with a mixture of $t$-BuLi/HMPA that allows hydrogen-selective exchange in presence of reactive electrophiles such as aldehydes, ketones and alkyl halides. This affords the corresponding product in moderate overall yield, after silyl enol ether cleavage and concomitant thiophenol elimination initiated with TBAF.
\end{abstract}

(c) 2017 Elsevier Ltd. All rights reserved.

\section{Introduction}

The development of new methods for the efficient construction of organic molecules continues to be essential for accessing natural products and their structural analogues. In this context, the concept of umpolung or polarity inversion is associated with a temporal masking of a functional group to reverse its polarity and perform secondary reactions that would otherwise not be possible. $^{1-3}$ Since retrosynthetic analysis was pioneered by E. J. Corey and co-workers in the early $1970 \mathrm{~s},{ }^{4}$ the umpolung approaches attracted more attention because it enables the usage of a wider variety of starting materials for building complex natural products. From the perspective of natural product synthesis, little is known about 2-cyclohexenone, a cheap and widely available compound with great synthetic potential. 2-cyclohexenone has been used to synthesize highly valuable molecules, such as antimalarial-drug (+)-artemisinin, via normal reactivity. ${ }^{5}$ An example of an umpolung strategy was described in a protocol for insertion of side chains at the 3-position of the 2-cyclohexenone allowed the formation of epoxyquinol analogues. ${ }^{6}$ For this reason, 3-substituted 2-cyclohexenones $\mathbf{4}$ are highlighted as recurrent building blocks for many purposes. They can be accessed through the umpolung reactivity of 2 -cyclohexenone by means of its synthetic equivalents such as 1,3bis(phenylthio)cyclohex-1-ene, ${ }^{7}$ 3-cyanocyclohexanone, ${ }^{8}$ 1-dioxo lanyl-3-tosylcyclohexane, ${ }^{9}$ or (3-(tert-butyldimethylsiloxy) cyclohex-2-en-1-yl)triphenylphosphonium triflate. ${ }^{10-12}$ These methods

\footnotetext{
* Corresponding author.

E-mail address: mromeroo@uaemex.mx (M. Romero-Ortega).
}

required multi-step transformations and overall yields are moderate.

An interesting and practical methodology to achieve the 3-electrophilic substitution of 2-cyclohexenone was reported by Katritzky's group in $1995 .{ }^{13}$ It consisted in the reaction between 2-cyclohexenone and trimethylsilylbenzotriazole to generate a 1,4-adduct similar to compound $\mathbf{2 b}$. Treatment of this nonisolated-intermediate with LDA promoted the formation of an allylic anion which was then trapped by an electrophile. Subsequent addition of aqueous acid obtained the corresponding 3-substituted 2-cyclohexenones 4 (yields 50-75\%).

On the other hand, Evans demonstrated in 1977 that (phenylthio)trimethylsilane $\mathbf{1} \mathbf{a}^{14,15}$ can be used as a protecting group of aldehydes and $\alpha, \beta$-unsaturated carbonyls due to the high affinity between silicon and oxygen atoms. Interestingly, the 1,4-adduct $2 \mathrm{a}$ that arises from the reaction between 1a and 2-cyclohexenone is also air-labile. Therefore, we thought that a more stable analogue such as (phenylthio)triisopropylsilane $\mathbf{1 b}$ might afford an analogue of 2a which also would undergo a 3-electrophilic substitution after its treatment with a base. Finally, TBAF would trigger a one-pot transformation of corresponding intermediates $\mathbf{3}$ into 3-susbtituted 2-cyclohexenones $\mathbf{4}$ as described in Scheme 1.

\section{Results and discussion}

The (phenylthio)silanes 1 were prepared using Davis' protocol. ${ }^{16}$ It involves a condensation between thiophenol and corresponding trialkylsilyl chloride in presence of $\mathrm{Et}_{3} \mathrm{~N}$. While triisopropyl 1b and $t$-butyldimethyl 1c derivatives were isolated 


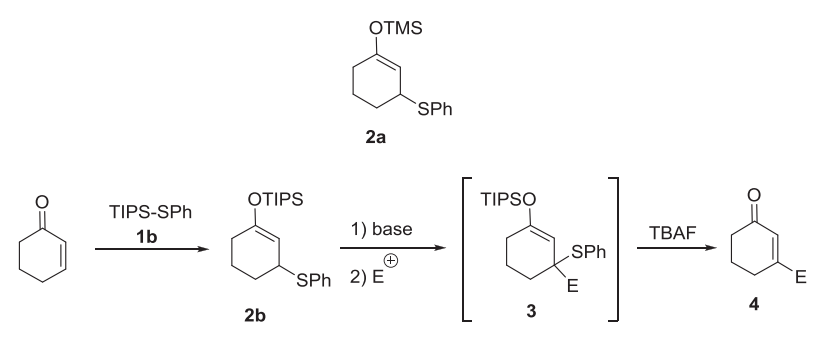

Scheme 1. General procedure to synthesize 3-substituted 2-cyclohexen-1-ones.

in yields of $80 \%$ and $54 \%$ respectively, the (phenylthio)trimethylsilane 1a was unstable during the heating process for vacuum distillation (Scheme 2). ${ }^{16 \mathrm{~b}}$

With compounds $\mathbf{1 b}$ and $\mathbf{1 c}$ at hand, we proceeded to find the best reaction conditions for generating 1,4-adducts 2 (Table 1). In the first experiment, a neat equimolar mixture of 2-cyclohexenone and (phenylthio)triisopropylsilane $\mathbf{1 b}$ did not afford any product 2b after stirring for $2 \mathrm{~h}$ even in the presence of potassium cyanide- 18 -crown- 6 complex ${ }^{17}(0.3 \% \mathrm{~mol})$ as initiator (Entry 1$)$. These conditions were reported by Evans to produce 2a using (phenylthio)trimethylsilane 1a. ${ }^{14,15}$ However, an increase in the reaction time to $18 \mathrm{~h}$ resulted in the desired compound $\mathbf{2 b}$, but with a poor yield of $21 \%$ (Entry 2). Moreover, when the amount of the anionic initiator was increased by 5 times with a reaction time of $2 \mathrm{~h}$, the yield was slightly improved to $28 \%$ (Entry 3 ). Interestingly, carrying out the reaction in THF, while applying $0.9 \%-\mathrm{mol}$ of the complex for $18 \mathrm{~h}$, dramatically increased the yield provided $\mathbf{2 b}$ to $60 \%$ (entry 4); a higher quantity of the complex, longer stirring time, or even heating, had a worse yield of the 1,4 -adduct $\mathbf{2 b}$. On the other hand, the treatment of 2-cyclohehexenone and (phenylthio)t-butyldimethylsilane 1c under similar conditions (THF, $0.9 \% \mathrm{~mol}$ of the complex, $18 \mathrm{~h}$ ), provided a moderate yield of compound 2c (37\%, entry 5).

Because of the 1,4-adduct $\mathbf{2 b}$ was obtained with the highest yield, we decided to take it as the synthetic equivalent of 2-cyclohexenone in order to develop our umpolung procedure. A typical experiment consisted in the reaction of a base and $\mathbf{2 b}$ at low temperatures, where the allylic anion could be trapped by an electrophile. Initial screening that employed $\mathrm{Ph}_{2} \mathrm{CO}$, allyl bromide,

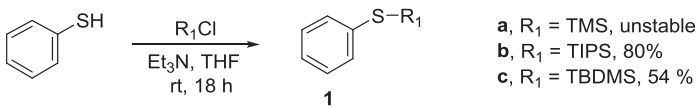

Scheme 2. Synthesis of (phenylthio)trialkylsilanes 1 . or PhCHO as electrophiles, demonstrated that bases such as LDA or $n$-BuLi were not sufficiently reactive to carry out the $\alpha$-lithiation of sulfide-derivative $\mathbf{2 b}$. In all these experiments only the starting material $\mathbf{2 b}$ was recovered. We believe that the reason for which the acid-base reaction did not happen was due to the short half-life time that $n$-BuLi exhibits in THF at $-78^{\circ} \mathrm{C} .{ }^{18,19}$ Likewise, the proton abstraction by the base on the sulfide $\mathbf{2 b}$ was not accomplished when $\mathrm{Et}_{2} \mathrm{O}$ was used instead of THF. Nor was it achieved by employing a much stronger base such as $t$-BuLi at $0{ }^{\circ} \mathrm{C}$. It is known that the presence of TMEDA or HMPA as additives has an important effect on the generation and stabilization of the respective carbanion. ${ }^{20}$ Consequently, when experiments were carried out at $0{ }^{\circ} \mathrm{C}$ in the presence of TMEDA using benzaldehyde as an electrophile, it was evident that the $\beta$-lithiation reaction took place in the thiophenyl ring instead of the $\alpha$-lithiation reaction of the sulfide-side of $\mathbf{2 b}$ because the alcohol $\mathbf{8}$ was isolated (Fig 1). It is worth noting that at $-78{ }^{\circ} \mathrm{C}$ the directed $o$-metalation of $\mathbf{2} \mathbf{b}$ did not occur in THF. The finding that TMEDA readily promotes the $\beta$-lithiation increased expectations for positive outcomes by using HMPA. Gratifyingly, when the reaction was carried out in THF/HMPA ( 2.5 equiv) at $-78{ }^{\circ} \mathrm{C}$, the expected anion of sulfide $2 \mathbf{b}$ was consumed by $\mathrm{PhCHO}$, resulting in intermediate 3a. The crude product 3a went through a slow one-pot process of deprotection $/ \beta$-elimination when TBAF was added, and ultimately led to the isolation of 2-cyclohexenone $\mathbf{4 a}$ with a yield of $71 \%$ (table 2, entry 1 ). This umpolung strategy was expanded when derivatives $\mathbf{4 b}$-h $\mathbf{h}$ were synthesized using $m$-anisaldehyde, piperonal, acetophenone, chloromethyl pivalate, benzyl bromide, 2-cyclohexenone and paraformaldehyde as electrophiles (Table 2). Hence, the procedure could be applied to ketones (Entry 4), alkyl halides (Entries 5-6) and even $\alpha, \beta$-unsaturated compounds such as 2-cyclohexenone (Entry 7). Here it is worth mentioning that this methodology comprises two continuous reactions in a single step, therefore yields are acceptable.

Aldehydes showed unusual behavior and exhibited a poor performance (Entries 2 and 3) especially paraformaldehyde (entry 8). We believe that low yields are due to an isomerization/oxidation process that happened, especially for 2-cyclohexenones $\mathbf{4 a}$ and $\mathbf{4 h}$ in a slightly acidic or basic media. For example, when 2-cyclo-

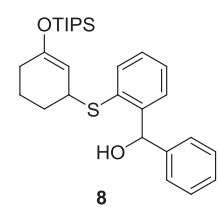

Fig. 1. o-Metallation of thiophenyl ring.

Table 1

Screening of the 2-cyclohexenone activation process.

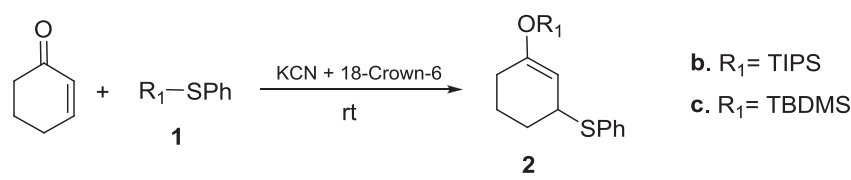

\begin{tabular}{|c|c|c|c|c|c|c|}
\hline Entry & SM & Complex (\%) & Solvent & Time (h) & Product & Yield (\%) \\
\hline 1 & 1b & 0.3 & neat & 2 & $2 \mathbf{b}$ & 0 \\
\hline 2 & $\mathbf{1 b}$ & 0.3 & neat & 18 & $2 \mathbf{b}$ & 21 \\
\hline 3 & 1b & 1.5 & neat & 2 & $\mathbf{2 b}$ & 28 \\
\hline 4 & $\mathbf{1 b}$ & 0.9 & THF & 18 & $\mathbf{2 b}$ & 60 \\
\hline 5 & $1 c$ & 0.9 & THF & 18 & $2 c$ & 37 \\
\hline
\end{tabular}


Table 2

Preparation of 3-substituted 2-cyclohexenones 4 by an umpolung electrophilicsubstitution procedure. ${ }^{\text {a }}$

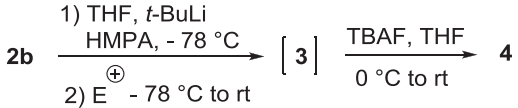

\begin{tabular}{llll}
\hline Entry & $\mathrm{E}^{+}$ & $\mathbf{4}(\mathrm{E}=)$ & Yield (\%) \\
\hline 1 & Benzaldehyde & 41 & \\
& &
\end{tabular}

Piperonal

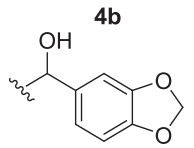

4

Acetophenone

$$
{ }_{4 d}^{\mathrm{HO}} \mathrm{Ph}_{\mathrm{Ph}}^{\mathrm{Me}}
$$

$5 \quad$ Chloromethyl pivalate

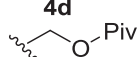

60

$6 \quad$ Benzyl bromide<smiles>[C+](CCCc1ccccc1)c1ccccc1</smiles>

50

$7 \quad$ Cyclohexenone

Paraformaldehyde

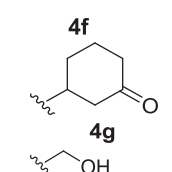

$4 \mathrm{~h}$

a Reactions were performed by using (phenylthio)silane $2 \mathbf{b}$ (1.0 equiv), HMPA (2.25 equiv), $t$-BuLi ( 2.25 equiv), $1.5-2.0$ equiv of $\mathrm{E}^{+}$, and TBAF (1.2 equiv).

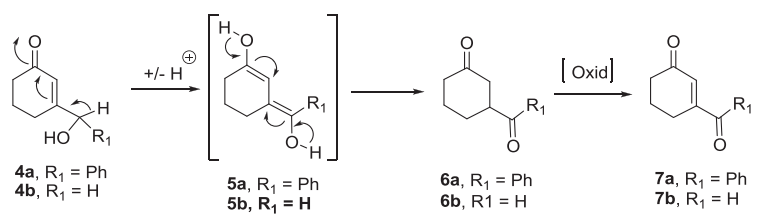

Scheme 3. Isomerization/oxidation of 2-cyclohexenones $\mathbf{4 a}$ and $\mathbf{4 b}$.

hexenones $\mathbf{4 a}$ or $\mathbf{4 h}$ remained dissolved in $\mathrm{CDCl}_{3}$ for a long time, the formation of compounds $\mathbf{7 a}$ and $\mathbf{7 h}$ was observed (Scheme 3 ). Apparently, delocalization of the electron density in the $\alpha, \beta$-unsaturated system would allow tautomerization to bis-enol intermediate 5 . Then, the keto-enol equilibrium would stimulate the obtaining of 1,4-dicarbonyl compound $\mathbf{6}$, which might be oxidized to the 2-cyclohexenones $\mathbf{7}$ by air. This mechanism of reaction was proposed because it was possible to isolate and characterize the 2-cyclohexanone $\mathbf{6 a}$ and the 2-cyclohexenone $7 \mathbf{a}$ after the reaction of 2-cyclohexenone $\mathbf{4 a}$ with TFA (1.0 equiv) in DCM at room temperature for $24 \mathrm{~h}$. Additionally, the oxidation of 3-(hydroxymethyl)-2-cyclohexenone $\mathbf{4 h}$ to the 3-carbaldehyde derivative 7h was also promoted by a base such as $\mathrm{K}_{2} \mathrm{CO}_{3}$. The observation of this behavior turned out to be relevant since it has not been previously described in the literature.

In summary, we have developed a novel and direct methodology for the preparation of 3-substituted 2-cyclohexenones 4 employing an umpolung strategy. The versatility and potential this methodology possess is revealed by the use of a variety of electrophilic species, notably the cheap and widely available 2-cyclohexenone, to generate in one-pot process 3-substituted 2-cyclohexenones $\mathbf{4}$ which could serve as useful buildings blocks to synthesize highly valuable molecules. Further investigation in this area is being carried out in our laboratory.

\section{Acknowledgments}

The Consejo Nacional de Ciencia y Tecnologia is gratefully acknowledged for providing a doctoral fellowship to Harim Lechuga (CONACyT 360339). The authors wish to thank M. Sc. Maria de las Nieves Zavala Segovia (CCIQS UNAM-UAEM) for obtaining NMR spectra, M. Sc. Lizbeth Triana Cruz for obtaining mass spectra and to Prof. Joseph M. Muchowski (UNAM) for helpful discussions and interests in our work.

\section{A. Supplementary data}

Supplementary data associated with this article can be found, in the online version, at http://dx.doi.org/10.1016/j.tetlet.2017.07. 007.

\section{References}

1. Seebach D, Corey EJ. J Org Chem. 1975;40:231.

2. GrÖBel B-T, Seebach D. Synthesis. 1977;357.

3. Seebach D. Angew Chem Int Ed. 1979;18:239.

4. Corey EJ. Pure Appl Chem. 1967;14:19.

5. Zhu C, Cook SP. J Am Chem Soc. 2012;134:13577.

6. Heguaburu V, Schapiro V, Pandolfi E. Tetrahedron Lett. 2010;51:6921.

7. Cohen T, Bennett DA, Mura AJ. J Org Chem. 1976;41:2506.

8. Debal A, Cuvigny TRS, Larchevêque M. Tetrahedron Lett. 1977;18:3187.

9. Huang P-Q, Zhou W-S. Synth Commun. 1991;21:2369.

10. Kozikowski AP, Jung SH. J Org Chem. 1986;51:3400.

11. Kim S, Lee PH. Tetrahedron Lett. 1988;29:5413.

12. Kim S, Lee PH, Kim SS. Bull Kor Chem Soc. 1989;10:218.

13. Katritzky AR, Soloducho J, Musgrave RP, Breytenbach JC. Tetrahedron Lett 1995;36:5491.

14. Evans DA, Grimm KG, Truesdale LK. J Am Chem Soc. 1975:97:3229.

15. Evans DA, Truesdale LK, Grimm KG, Nesbitt SL. J Am Chem Soc. 1977;99:5009.

16. (a) Davis FA, Rizvi SQA, Ardecky R, Gosciniak DJ, Friedman AJ, Yocklovich SG. Org Chem. 1980:45:1650

(b) Synthesis of phenyl(trialkylsilyl)sulfides $\mathbf{1 b}$ and $\mathbf{1 c}$. To a solution of thiophenol (1.0 equiv) and the corresponding trialkylsilyl chloride (1.1 equiv) in anhydrous THF $[1.95 \mathrm{M}]$, under nitrogen atmosphere, triethylamine (1.2 equiv) dissolved in anhydrous THF [2.37 M] was added dropwise. Immediately the triethylammonium chloride is observed as a white solid. After stirring for $18 \mathrm{~h}$ at room temperature, the reaction mixture was filtered through celite, the filter was washed with $10 \mathrm{~mL}$ of THF, and the filtrate was washed with $10 \mathrm{~mL}$ of an aqueous solution of $\mathrm{KOH}(10 \%)$ in order to eliminate the excess of tiophenol. The organic layers were dried over $\mathrm{Na}_{2} \mathrm{SO}_{4}$ and evaporated in vacuo. The crude reaction was then distillated under reduced pressure affording the corresponding phenyl(trialkylsilyl)sulfide 1.Compound 1b: The general procedure was applied using $1.0 \mathrm{~mL}$ of thiophenol $(1.073 \mathrm{~g}$ $9.74 \mathrm{mmol}), 2.3 \mathrm{~mL}$ of TIPSCl $(2.072 \mathrm{~g}, 10.75 \mathrm{mmol})$ in $5 \mathrm{~mL}$ of anhydrous THF This reaction afforded $2.07 \mathrm{~g}(80 \%)$ of $\mathbf{2 b}$ as a colorless oil. TLC- $\mathrm{R}_{\mathrm{f}}$ (Hexanes $100 \%) 0.62$; bp $109{ }^{\circ} \mathrm{C}(9.0 \mathrm{mmHg}) ; \mathrm{NMR}-{ }^{1} \mathrm{H}\left(300 \mathrm{MHz}, \mathrm{CDCl}_{3}\right) \delta 7.50$ (dd $J=6.5,3.0 \mathrm{~Hz}, 2 \mathrm{H}), 7.24-7.18(\mathrm{~m}, 3 \mathrm{H}), 1.25(\mathrm{ddd}, J=15.6,13.0,7.1 \mathrm{~Hz}, 3 \mathrm{H}), 1.09$ $(\mathrm{d}, J=7.1 \mathrm{~Hz}, 18 \mathrm{H}) ; \mathrm{NMR}-{ }^{13} \mathrm{C}\left(75 \mathrm{MHz}, \mathrm{CDCl}_{3}\right) \delta 135.4,131.5,128.5,126.6,18.4$ 13.1. Mass spectrum $m / z\left[\mathrm{M}^{+}\right] 266,223(100 \%)$.Compound $1 \mathrm{c}:{ }^{16}$ The general procedure was applied using $1.0 \mathrm{~mL}$ of thiophenol $(1.073 \mathrm{~g}, 9.74 \mathrm{mmol}), 1.62 \mathrm{~g}$ of TBDMSCl $(10.75 \mathrm{mmol})$ in $5 \mathrm{~mL}$ of anhydrous THF. This reaction afforded $1.173 \mathrm{~g}(54 \%)$ of $1 \mathrm{c}$ as a colorless oil. TLC- $\mathrm{R}_{\mathrm{f}}$ (Hexanes $\left.100 \%\right) 0.55$; bp $90{ }^{\circ} \mathrm{C}(9.0$ $\mathrm{mmHg}) ; \mathrm{NMR}-{ }^{1} \mathrm{H}\left(300 \mathrm{MHz}, \mathrm{CDCl}_{3}\right) \delta 7.26$ (dd, $\left.J=6.6,3.0 \mathrm{~Hz}, 2 \mathrm{H}\right), 7.08-7.01$ $(\mathrm{m}, 3 \mathrm{H}), 0.80(\mathrm{~s}, 9 \mathrm{H}),-0.00(\mathrm{~s}, 6 \mathrm{H}) ; \mathrm{NMR}-{ }^{13} \mathrm{C}\left(75 \mathrm{MHz}, \mathrm{CDCl}_{3}\right) \delta 135.6,131.5$, 128.6, 126.8, 26.4, 19.0, -3.3.Synthesis of 3-phenylthio-1-(trialkylsilyloxy)cyclohex-1-ene 2: The KCN/18-crown-6 complex was added to a well-stirred solution of 2-cyclohexenone (1.0 equiv) and the respective phenyl(trialkylsilyl)sulfide (1.0 equiv) in freshly distilled dry THF [1.6 M]. Stirring under nitrogen atmosphere at room temperature was continued for $18 \mathrm{~h}$ and the yellow solution was concentrated in vacuum and the products were obtained as oils and used in their crude form.Compound $\mathbf{2 b}$ : The general procedure was applied using $376 \mathrm{mg}$ of 2-cyclohexenone (3.91 mmol), $1.04 \mathrm{~g}$ of $\mathbf{1 b}$ and $12 \mathrm{mg}$ of KCN/18-crown-6 complex $(0.04 \mathrm{mmol})$ in anhydrous THF $(2.5 \mathrm{~mL})$. The reaction crude was purified by column chromatography $(4.0 \times 10.0 \mathrm{~cm}$, silica gel; Hexanes $100 \%)$, affording $847 \mathrm{mg}(60 \%)$ of $\mathbf{2 b}$ as a yellow pallid oil. TLC-R 
(Hexanes, 100\%) 0.26; NMR- ${ }^{1} \mathrm{H}\left(300 \mathrm{MHz}, \mathrm{CDCl}_{3}\right) \delta 7.39(\mathrm{~d}, J=7.1 \mathrm{~Hz}, 2 \mathrm{H}), 7.27$ $(\mathrm{t}, J=7.3 \mathrm{~Hz}, 2 \mathrm{H}), 7.20(\mathrm{~d}, J=7.1 \mathrm{~Hz}, 1 \mathrm{H}), 4.99(\mathrm{~d}, J=4.4 \mathrm{~Hz}, 1 \mathrm{H}), 3.99(\mathrm{~d}, J=4.2$ $\mathrm{Hz}, 1 \mathrm{H}), 2.14-1.94(\mathrm{~m}, 3 \mathrm{H}), 1.72$ (ddtq, $J=27.8,22.2,11.6,5.8,5.2 \mathrm{~Hz}, 3 \mathrm{H}$ ), $1.17-0.98(\mathrm{~m}, 21 \mathrm{H})$; NMR- ${ }^{13} \mathrm{C}\left(126 \mathrm{MHz}, \mathrm{CDCl}_{3}\right) \delta 154.4,136.4,131.3,128.7$, $126.4,103.7,44.9,29.8,28.1,19.2,18.0,12.6$. MS (EI, $70 \mathrm{eV}) \mathrm{m} / z\left[\mathrm{M}^{+}\right] 361,255$ (100\%).t-butyldimethyl(((3-(phenylthio)cyclohex-1-en-1-yl)oxy)silane (2c). The general procedure was applied using $100 \mathrm{mg}$ of cyclohexenone $(1.04 \mathrm{mmol}), 233 \mathrm{mg}$ of $1 \mathrm{c}$ and $5.0 \mathrm{mg}$ of $\mathrm{KCN} / 18$-crown-6 complex $(0.02 \mathrm{mmol})$ in $0.8 \mathrm{~mL}$ of anhydrous THF. The product was purified by column chromatography $(3.0 \times 9.0 \mathrm{~cm}$, silica gel; Hexanes $100 \%)$, affording $123 \mathrm{mg}$

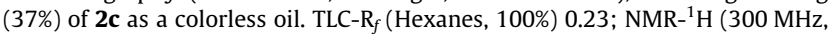
$\left.\mathrm{CDCl}_{3}\right) \delta 7.26(\mathrm{~d}, J=6.6 \mathrm{~Hz}, 2 \mathrm{H}), 7.10(\mathrm{dd}, J=16.0,6.9 \mathrm{~Hz}, 3 \mathrm{H}), 4.85(\mathrm{~s}, 1 \mathrm{H}), 3.83$ (s, $1 \mathrm{H}), 1.89(\mathrm{~s}, 3 \mathrm{H}), 1.71-1.43(\mathrm{~m}, 3 \mathrm{H}), 0.78(\mathrm{~s}, 9 \mathrm{H}), 0.00(\mathrm{~s}, 6 \mathrm{H})$; NMR- ${ }^{13} \mathrm{C}$ $\left(126 \mathrm{MHz}, \mathrm{CDCl}_{3}\right) \delta 154.2,136.3,131.3,128.8,126.5,104.4,44.8,29.8,28.2$, $25.6,19.1,18.0,-4.4,-4.5$.Synthesis of 2-cyclohexen-1-one-3-sustituted 4. A solution of 1.0 equiv of $\mathbf{2 b}$ and HMPA (2.0-2.5 equiv) in anhydrous THF $[0.092 \mathrm{M}]$ was cooled at $-78^{\circ} \mathrm{C}\left(\mathrm{N}_{2}\right.$ atmosphere). $t$-BuLi (1.5 M, 2.0-2.5 equiv) was added dropwise over 5 min period. Stirring at $-78{ }^{\circ} \mathrm{C}$ was continued for $30 \mathrm{~min}$, and then the respective electrophile (1.5-2.0 equiv) was added and then the reaction mixture was stirred for $30 \mathrm{~min}$ at $-78^{\circ} \mathrm{C}$. The reaction temperature was allowed to rise to room temperature for $2 \mathrm{~h}$ and the reaction was quenched with saturated $\mathrm{NH}_{4} \mathrm{Cl}$ solution. The product was extracted with EtOAc $(3 \times 15 \mathrm{~mL})$. The combined organic layers were dried over $\mathrm{Na}_{2} \mathrm{SO}_{4}$, filtered and concentrated in vacuum. The crude reaction was dissolved in anhydrous THF $[0.069 \mathrm{M}]$ and was cooled at $0{ }^{\circ} \mathrm{C}$. TBAF $(1.0 \mathrm{M}, 1.25$ equiv) was added and the reaction temperature was allowed to rise the room temperature and stirred for $18 \mathrm{~h}$. At the end of this period of time, the reaction was quenched by adding brine and the product was extracted with EtOAc $(3 \times 15 \mathrm{~mL})$. The combined organic layers were dried over $\mathrm{Na}_{2} \mathrm{SO}_{4}$, filtered and concentrated in vacuum and the product was purified by column chromatography on silica gel.Compound $\mathbf{4 a}{ }^{13}$ The general procedure was applied using $105 \mathrm{mg}$ of $\mathbf{2 b}(0.28 \mathrm{mmol}), 0.10 \mathrm{~mL}$ of HMPA (103 mg, $0.58 \mathrm{mmol}), t$-BuLi $(0.45 \mathrm{~mL}, 1.5 \mathrm{M}, 0.60 \mathrm{mmol})$ and $65 \mu \mathrm{L}$ of benzaldehyde (63 mg, $0.59 \mathrm{mmol}$ ) in $3.5 \mathrm{~mL}$ of anhydrous THF. For the deprotection $0.36 \mathrm{~mL}$ of TBAF $(1.0 \mathrm{M}, 95 \mathrm{mg}, 0.36 \mathrm{mmol})$ were used in $4 \mathrm{~mL}$ anhydrous THF. The reaction crude was purified by column chromatography $(2.0 \times 8.0 \mathrm{~cm}$, silica gel; $55: 45$ Hexanes/EtOAc) affording $41 \mathrm{mg}(71 \%)$ of $\mathbf{4 a}$ as a yellow oil. TLC- $\mathrm{R}_{f}$ (Hexanes/EtOAc 3:2) 0.23; NMR- ${ }^{1} \mathrm{H}\left(300 \mathrm{MHz} \mathrm{CDCl}_{3}\right) \delta 7.41-7.30(\mathrm{~m}, 5 \mathrm{H}), 6.35$ $(\mathrm{d}, J=1.4 \mathrm{~Hz}, 1 \mathrm{H}), 5.24(\mathrm{~s}, 1 \mathrm{H}), 2.38(\mathrm{t}, J=6.6 \mathrm{~Hz}, 2 \mathrm{H}), 2.27(\mathrm{~s}, 1 \mathrm{H}), 2.15(\mathrm{t}, J=5.5$ $\mathrm{Hz}, 2 \mathrm{H}), 1.93$ (dq, $J=12.2,7.0,6.3 \mathrm{~Hz}, 2 \mathrm{H})$; NMR ${ }^{13} \mathrm{C}\left(75 \mathrm{MHz}, \mathrm{CDCl}_{3}\right) \delta 200.0$, 165.0, 140.4, 128.9, 128.6, 126.8, 124.0, 76.7 , 37.8, 25.9, 22.6. Mass spectrum $\mathrm{m} / \mathrm{z}\left[\mathrm{M}^{+}\right] 246,93(84 \%)$.Compound $\mathbf{4 b}$ : The general procedure was applied using $100 \mathrm{mg}$ of $\mathbf{2 b}(0.28 \mathrm{mmol}), 0.12 \mathrm{~mL}$ of HMPA $(124 \mathrm{mg}, 0.69 \mathrm{mmol}), t$-BuLi $(0.45 \mathrm{~mL}, 1.5 \mathrm{M}, 0.60 \mathrm{mmol})$ and $70 \mu \mathrm{L}$ of m-anisaldehyde (75 mg, $0.55 \mathrm{mmol}$ ) in $3.0 \mathrm{~mL}$ of anhydrous THF. For the deprotection $0.33 \mathrm{~mL}$ of TBAF $(1.0 \mathrm{M}$, $86 \mathrm{mg}, 0.33 \mathrm{mmol}$ ) were used in $4 \mathrm{~mL}$ anhydrous THF. The product was purified by column chromatography $(2.0 \times 10.0 \mathrm{~cm}$, silica gel; 55:45 Hexanes/EtOAc) affording $24 \mathrm{mg}(38 \%)$ of $\mathbf{4 b}$ as a yellow pallid oil. TLC- $\mathrm{R}_{f}$ (Hexanes/EtOAc 55:45) 0.30; ${ }^{1} \mathrm{H}$ NMR $\left(300 \mathrm{MHz}, \mathrm{CDCl}_{3}\right) \delta 7.20(\mathrm{~d}, J=7.6 \mathrm{~Hz}, 3 \mathrm{H}), 6.87-6.78(\mathrm{~m}$, $3 \mathrm{H}), 6.27(\mathrm{~s}, 1 \mathrm{H}), 5.14(\mathrm{~s}, 1 \mathrm{H}), 3.74(\mathrm{~s}, 3 \mathrm{H}), 2.34-2.28(\mathrm{~m}, 2 \mathrm{H}), 2.13-2.07(\mathrm{~m}, 2 \mathrm{H})$, $1.86(\mathrm{~d}, J=6.3 \mathrm{~Hz}, 3 \mathrm{H}), 1.26(\mathrm{~s}, 1 \mathrm{H}) ;{ }^{13} \mathrm{C}$ NMR $\left(75 \mathrm{MHz}, \mathrm{CDCl}_{3}\right) \delta 200.09,165.00$, $159.99,142.07,129.90,124.05,119.07,113.92,55.29,37.79,25.82,22.60 . M a s s$ spectrum $m / z\left[\mathrm{M}^{+}\right] 232,232(100 \%)$.Compound $4 \mathrm{c}$ : The general procedure was applied using $100 \mathrm{mg}$ of $\mathbf{2 b}(0.28 \mathrm{mmol}), 0.12 \mathrm{~mL}$ of HMPA (124 mg, $0.69 \mathrm{mmol}), t$-BuLi $(0,45 \mathrm{~mL}, 1.5 \mathrm{M}, 0.60 \mathrm{mmol})$ and $83 \mathrm{mg}$ of piperonal (dissolved in $1 \mathrm{~mL}$ of THF, $0.55 \mathrm{mmol}$ ) in $3.0 \mathrm{~mL}$ of anhydrous THF. For the deprotection $0.33 \mathrm{~mL}$ of TBAF $(1.0 \mathrm{M}, 86 \mathrm{mg}, 0.33 \mathrm{mmol})$ were used in $4 \mathrm{~mL}$ anhydrous THF. The reaction crude was purified by column chromatography $(2.0 \times 8.0 \mathrm{~cm}$, silica gel; $55: 45$ Hexanes/EtOAc) affording $18 \mathrm{mg}(27 \%)$ of $4 \mathrm{c}$ as a yellow pallid oil. TLC-R $\left(\right.$ Hexanes/EtOAc 55:45) $0.30 ;{ }^{1} \mathrm{H}$ NMR $(300 \mathrm{MHz}$, $\left.\mathrm{CDCl}_{3}\right) \delta 6.82(\mathrm{~d}, J=5.3 \mathrm{~Hz}, 3 \mathrm{H}), 6.34(\mathrm{~d}, J=1.5 \mathrm{~Hz}, 1 \mathrm{H}), 5.98(\mathrm{~s}, 2 \mathrm{H}), 5.15(\mathrm{~s}, 1 \mathrm{H})$, $2.44-2.35(\mathrm{~m}, 3 \mathrm{H}), 2.15$ (d, $J=J=6.0 \mathrm{~Hz}, 2 \mathrm{H}), 2.00-1.88(\mathrm{~m}, 2 \mathrm{H}), 1.34(\mathrm{~s}, 1 \mathrm{H})$;
${ }^{13} \mathrm{C}$ NMR $\left(75 \mathrm{MHz}, \mathrm{CDCl}_{3}\right) \delta 200.06,165.19,148.13,147.79,134.42,123.80$, $120.60,108.35,107.06,101.25,37.79,25.99,22.60$. Mass spectrum $m / z\left[\mathrm{M}^{+}\right]$ 246.Compound 4d: The general procedure was applied using $100 \mathrm{mg}$ of $\mathbf{2 b}$ $(0.28 \mathrm{mmol}), 0.12 \mathrm{~mL}$ of HMPA $(124 \mathrm{mg}, 0.69 \mathrm{mmol}), t$-BuLi $(0.45 \mathrm{~mL}, 1.5 \mathrm{M}$, $0.675 \mathrm{mmol}$ ) and $70 \mu \mathrm{L}$ of acetophenone $(72 \mathrm{mg}, 0.60 \mathrm{mmol}$ ) in $3.0 \mathrm{~mL}$ of anhydrous THF. For the deprotection $0.33 \mathrm{~mL}$ of TBAF $(1.0 \mathrm{M}, 86 \mathrm{mg}$, $0.33 \mathrm{mmol}$ ) were used in $4 \mathrm{~mL}$ anhydrous THF. The reaction crude was purified by column chromatography $(2.0 \times 10.0 \mathrm{~cm}$, silica gel; 65:35 Hexanes/EtOAc)

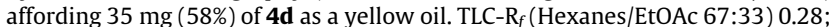
NMR- ${ }^{1} \mathrm{H}\left(300 \mathrm{MHz}, \mathrm{CDCl}_{3}\right) \delta 7.44-7.28(\mathrm{~m}, 5 \mathrm{H}), 6.35(\mathrm{~s}, 1 \mathrm{H}), 2.37(\mathrm{t}, J=6.6,6.2$ $\mathrm{Hz}, 2 \mathrm{H}), 2.22-2.11(\mathrm{~m}, 2 \mathrm{H}), 2.06(\mathrm{~s}, 1 \mathrm{H}), 1.87(\mathrm{p}, J=6.1,5.6 \mathrm{~Hz}, 2 \mathrm{H}), 1.76(\mathrm{~s}, 3 \mathrm{H})$; NMR- ${ }^{13} \mathrm{C}\left(75 \mathrm{MHz}, \mathrm{CDCl}_{3}\right) \delta 200.5,168.6,144.2,128.6,127.7,125.3,123.6,76.4$, 37.6, 27.5, 25.9, 23.0. Mass spectrum $m / z\left[\mathrm{M}^{+}\right] 217,173$ (100\%).Compound $4 \boldsymbol{e}:{ }^{21}$ The general procedure was applied using $100 \mathrm{mg}$ of $\mathbf{2 b}(0.28 \mathrm{mmol}), 0.12 \mathrm{~mL}$ of HMPA (124 mg, $0.69 \mathrm{mmol}), 0.45 \mathrm{~mL}$ of $t$-BuLi $(0.45 \mathrm{~mL}, 1.5 \mathrm{M}, 0.675 \mathrm{mmol})$ and $90 \mu \mathrm{L}$ of chloromethyl pivalate $(94 \mathrm{mg}, 0.62 \mathrm{mmol}$ ) in $3.0 \mathrm{~mL}$ of anhydrous THF. For the deprotection $0.33 \mathrm{~mL}$ of TBAF $(1.0 \mathrm{M}, 86 \mathrm{mg}, 0.33 \mathrm{mmol})$ were used in $4 \mathrm{~mL}$ anhydrous THF. The reaction crude was purified by column chromatography $(2.0 \times 10.0 \mathrm{~cm}$, silica gel; $4: 1$ Hexanes/EtOAc $)$ affording $35 \mathrm{mg}$ (60\%) of $4 \mathbf{e}$ as a yellow pallid oil. TLC-R $\left(\right.$ Hexanes/EtOAc 4:1) 0.28 ; NMR- ${ }^{1} \mathrm{H}$ $\left(300 \mathrm{MHz}, \mathrm{CDCl}_{3}\right) \delta 6.02(\mathrm{~s}, 1 \mathrm{H}), 4.67(\mathrm{~s}, 2 \mathrm{H}), 2.43(\mathrm{t}, J=6.0,5.5 \mathrm{~Hz}, 2 \mathrm{H}), 2.28(\mathrm{t}$, $J=6.5,5.5 \mathrm{~Hz}, 2 \mathrm{H}), 2.05(\mathrm{q}, J=10.5,5.1 \mathrm{~Hz}, 2 \mathrm{H}), 1.25(\mathrm{~s}, 9 \mathrm{H}) ; \mathrm{NMR}-{ }^{13} \mathrm{C}(75 \mathrm{MHz}$, $\left.\mathrm{CDCl}_{3}\right) \delta 199.0,177.7,158.7,124.3,64.8,38.9,37.6,27.2,26.3,22.3$. Compound $\mathbf{4 f :}:{ }^{22}$ The general procedure was applied using $100 \mathrm{mg}$ of $\mathbf{2 b}(0.28 \mathrm{mmol})$, $0.12 \mathrm{~mL}$ of HMPA $(124 \mathrm{mg}, 0.69 \mathrm{mmol}), t$-BuLi $(0.45 \mathrm{~mL}, 1.5 \mathrm{M}, 0.675 \mathrm{mmol})$ and $66 \mu \mathrm{L}$ of benzyl bromide ( $96 \mathrm{mg}, 0.55 \mathrm{mmol}$ ) in $3.0 \mathrm{~mL}$ of anhydrous THF. For the deprotection $0.33 \mathrm{~mL}$ of TBAF $(1.0 \mathrm{M}, 86 \mathrm{mg}, 0.33 \mathrm{mmol})$ were used in $4 \mathrm{~mL}$ anhydrous THF. The reaction crude was purified by column chromatography $(2.0 \times 10.0 \mathrm{~cm}$, silica gel; 3:2 Hexanes/EtOAc) affording $23.1 \mathrm{mg}(45 \%)$ of

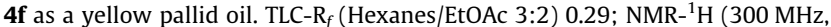
$\left.\mathrm{CDCl}_{3}\right) \delta 7.39-7.31(\mathrm{~m}, 5 \mathrm{H}), 6.35(\mathrm{~d}, J=1.3 \mathrm{~Hz}, 1 \mathrm{H}), 5.30(\mathrm{~s}, 1 \mathrm{H}), 5.24(\mathrm{~s}, 1 \mathrm{H})$, $2.38(\mathrm{t}, J=6.4 \mathrm{~Hz}, 2 \mathrm{H}), 2.16(\mathrm{t}, J=J=5.9 \mathrm{~Hz}, 2 \mathrm{H}), 1.94(\mathrm{p}, J=12.6,6.1 \mathrm{~Hz}, 2 \mathrm{H})$; NMR- ${ }^{13} \mathrm{C}\left(126 \mathrm{MHz}, \mathrm{CDCl}_{3}\right) \delta 200.1,165.2,140.4,128.8,128.5,126.8,124.0$, 76.7, 37.8, 25.9, 22.6.Compound $\mathbf{4 g}$ : The general procedure was applied using $100 \mathrm{mg}$ of $\mathbf{2 b}(0.28 \mathrm{mmol}), 0.12 \mathrm{~mL}$ of HMPA $(124 \mathrm{mg}, 0.69 \mathrm{mmol}), t$-BuLi $(0.45 \mathrm{~mL}, 1.5 \mathrm{M}, 0.675 \mathrm{mmol})$ and $50 \mu \mathrm{L}$ of 2-cyclohexen-1-one (50 mg, $0.52 \mathrm{mmol}$ ) in $3.0 \mathrm{~mL}$ of anhydrous THF. For the deprotection $0.33 \mathrm{~mL}$ of TBAF $(1.0 \mathrm{M}, 86 \mathrm{mg}, 0.33 \mathrm{mmol})$ were used in $4 \mathrm{~mL}$ anhydrous THF. The reaction crude was purified by column chromatography $(2.0 \times 8.0 \mathrm{~cm}$, silica gel; $55: 45$ Hexanes/EtOAc) affording $29 \mathrm{mg}(55 \%)$ of $\mathbf{4 g}$ as a white solid. TLC-R (Hexanes/ EtOAc 1:1) 0.36; m.p.: $46-48{ }^{\circ} \mathrm{C}$; NMR- ${ }^{1} \mathrm{H}\left(500 \mathrm{MHz}, \mathrm{CDCl}_{3}\right) \delta 5.89$ (d, $J=1.1 \mathrm{~Hz}$, $1 \mathrm{H}), 2.58-2.37(\mathrm{~m}, 5 \mathrm{H}), 2.36-2.28(\mathrm{~m}, 4 \mathrm{H}), 2.16$ (ddt, $J=13.0,6.5,3.2 \mathrm{~Hz}, 1 \mathrm{H})$, 2.02 (dt, $J=12.6,6.1 \mathrm{~Hz}, 3 \mathrm{H}), 1.75-1.63(\mathrm{~m}, 2 \mathrm{H})$; NMR- ${ }^{13} \mathrm{C}$ NMR $(75 \mathrm{MHz}$, $\left.\mathrm{CDCl}_{3}\right) \delta 209.55,199.70,166.30,124.81,45.87,45.47,41.07,37.48,29.40$ $28.18,25.13,22.77$.Mass spectrum $\mathrm{m} / \mathrm{z}\left[\mathrm{M}^{+}\right] 192,95$ (100\%).3-(hydroxymethyl)cyclohex-2-en-1-one (4h): ${ }^{21}$ The general procedure was applied using $100 \mathrm{mg}$ of $147 \mathrm{~b}(0.28 \mathrm{mmol}), 0.12 \mathrm{~mL}$ of HMPA $(124 \mathrm{mg}, 0.69 \mathrm{mmol}), t$-BuLi $(0.45 \mathrm{~mL}$, $1.5 \mathrm{M}, 0.675 \mathrm{mmol})$ and $35 \mathrm{mg}$ of paraformaldehyde $(1.2 \mathrm{mmol})$ in $3.0 \mathrm{~mL}$ of anhydrous THF. For the deprotection $0.33 \mathrm{~mL}$ of TBAF $(1.0 \mathrm{M}, 86 \mathrm{mg}$, $0.33 \mathrm{mmol}$ ) were used in $4 \mathrm{~mL}$ anhydrous THF. The reaction crude was purified by column chromatography $(2.0 \times 8.0 \mathrm{~cm}$, silica gel; $3: 7$ Hexanes/EtOAc $)$

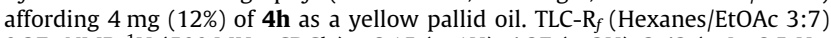
0.27; NMR- ${ }^{1} \mathrm{H}\left(500 \mathrm{MHz}, \mathrm{CDCl}_{3}\right) \delta 6.15(\mathrm{~s}, 1 \mathrm{H}), 4.27(\mathrm{~s}, 2 \mathrm{H}), 2.42(\mathrm{t}, J=6.5 \mathrm{~Hz}$, $2 \mathrm{H}), 2.27(\mathrm{t}, J=5.7 \mathrm{~Hz}, 2 \mathrm{H}), 2.04(\mathrm{p}, J=14.9,6.9,6.2 \mathrm{~Hz}, 2 \mathrm{H}) ; \mathrm{NMR}^{-13} \mathrm{C}$ $\left(126 \mathrm{MHz}, \mathrm{CDCl}_{3}\right) \delta 199.2,166.9,123.3,65.0,37.8,26.1,22.5$.

17. Evans DA, Truesdale LK. Tetrahedron Lett. 1973;14:4929.

18. Jung ME, Blum RB. Tetrahedron Lett. 1977;18:3791.

19. Stanetty P, Koller H, Mihovilovic M. J Org Chem. 1992;57:6833.

20. Dolak TM, Bryson TA. Tetrahedron. Let.. 1977;18:1961.

21. Lechuga-Eduardo H, Romero-Ortega M, Olivo HF. Eur J Org Chem. 2016;51.

22. Kozikowski AP, Jung SH. J Org Chem. 1986;51:3402. 